\title{
GARSHUNI AS IT IS: SOME OBSERVATIONS FROM READING EAST AND WEST SYRIAC MANUSCRIPTS
}

\author{
ADAM CARTER MCCOLLUM \\ HILL MUSEUM \& MANUSCRIPT LIBRARY
}

\begin{abstract}
Syriac script has been used to write several languages other than Syriac, the most well known of which is Arabic, a phenomenon known generally and simply as Garshuni. While both Syriac and Arabic belong to the Semitic family of languages and thus share some phonological similarities, there are also differences. In addition, we are dealing with well-established written traditions on both sides, Syriac and Arabic, but we are also dealing with, on the Arabic side, a reading tradition influenced more or less by the reader's own Arabic dialect, and thus a reading tradition that does not necessarily have Classical Arabic as its absolute model. Syriac script has a smaller inventory of letters than Arabic script, and while scribes often used diacritical marks to fill out this deficiency, that practice was hardly universal. In an ideal situation, there might be exact correspondences between this Syriac letter (or letter plus diacritic) and that Arabic letter, and such an ideal appears in published charts to describe Garshuni, but manuscripts vary widely from this tidy ideal, and it is the purpose of this paper to highlight that variety with examples from several manuscripts.
\end{abstract}




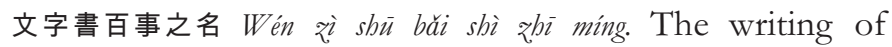
words writes the names of many things.

尚書注疏 Shàng shū ₹̧ù shū by (pseudo-)Kong Anguo ${ }^{1}$

Ainsi, bien qu l'écriture soit en elle-même étrangère au système interne, il est impossible de faire abstraction d'un procédé par lequel la langue est sans cesse figurée; il est nécessaire d'en connaittre l'utilité, les défauts et les dangers. La langue a donc une tradition orale indépendante de l'écriture, et bien autrement fixe; mais le prestige de la forme écrite nous empêche de le voir.

...l'écriture voile la vue de la langue: elle n'est pas un vêtement, mais un travestissement.

Ce qui fixe la pronunciation d'un mot, ce n'est pas son orthographe, c'est son histoire.

Ferdinand de Saussure, Cours de linguistique générale, Intr., ch. VI

\section{INTRODUCTION}

De Saussure's remarks about writing over against language as spoken do not always broadly apply to Arabic as written in Syriac letters, the phenomenon usually known simply as Garshuni. It lacks the more fixed systematization found in the writing systems as envisioned by him, and the prestige he speaks of, where present, was a prestige probably known and appreciated only by a relatively small number of readers. In this paper, I do not aim to offer a general presentation of ideal or standardized Arabic Garshuni (hereafter referred to simply as "Garshuni"), for which there are some brief introductions. My goal is rather to highlight the variety in which Arabic texts were presented in Syriac letters: that is to say,

${ }^{1}$ Translation adapted from Yushu Gong, Haiying Yan, Yinghui Ge, "The Accounts of the Origin of Writing from Sumer, Egypt and China A Comparative Perspective," WZKM 99 (2009): 137-158, here 146 and 156, where the sentence is quoted. Kong Anguo (孔安國 Kŏng ān guô) lived c. 156-c. 74 BCE (Wilkinson, p. 696, gives the year of his death as 100 BCE), but this work is a fourth-century forgery. See further Endymion Wilkinson, Chinese History: A New Manual (Harvard University Asia Center: Cambridge, Mass. and London, 2013), 370, 696-697; and Dominik Declercq, Writing Against the State: Political Rhetorics in Third and Fourth Century China, Sinica Leidensia 39 (Leiden: Brill, 1998), 169-170. 
that it is hard to seriously envision any ideal or standardized Garshuni if we take manuscripts as our evidence. By accepting without a grain of salt a simplified and tidy survey of Garshuni, unwary readers unexposed to manuscripts might be misled into assuming that Garshuni is more uniform than it really is, and I hope to dispel any such notions. What follows, then, is a focus on some of this variety as found in a sampling of Garshuni manuscripts written in both the East and West Syriac scripts.

For convenience, here is a table of most of the manuscripts cited below, with indication of whether they are in East or West Syriac script and their date.

\begin{tabular}{|c|c|c|c|c|}
\hline Shelfmark & Date & Script & City & Collection \\
\hline CCM 3 & $18^{\text {th }} / 19^{\text {th }}$ & ES & Mardin & Chaldean Cathedral \\
\hline CCM 7 & $18^{\text {th }}$ & ES & Mardin & Chaldean Cathedral \\
\hline CCM 8 & 1681 & ES & Mardin & Chaldean Cathedral \\
\hline CCM 10 & $18^{\text {th }}$ & ES & Mardin & Chaldean Cathedral \\
\hline CCM 11 & $17^{\text {th }} / 18^{\text {th }}$ & ES & Mardin & Chaldean Cathedral \\
\hline CCM 13 & 1719 & $\mathrm{ES}$ & Mardin & Chaldean Cathedral \\
\hline CCM 16 & $17^{\text {th }}$ & WS & Mardin & Chaldean Cathedral \\
\hline CCM 18 & $1609 / 10$ & ES & Mardin & Chaldean Cathedral \\
\hline CCM 54 & 1628 & ES & Mardin & Chaldean Cathedral \\
\hline CCM 63 & $17^{\text {th }}$ & ES & Mardin & Chaldean Cathedral \\
\hline CFMM 10 & $18^{\text {th }}$ & WS & Mardin & $\begin{array}{l}\text { Church of the Forty } \\
\text { Martyrs }\end{array}$ \\
\hline CFMM 125 & $18^{\text {th }} / 19^{\text {th }}$ & WS & Mardin & $\begin{array}{l}\text { Church of the Forty } \\
\text { Martyrs }\end{array}$ \\
\hline CFMM 256 & 1665 & WS & Mardin & $\begin{array}{l}\text { Church of the Forty } \\
\text { Martyrs }\end{array}$ \\
\hline CFMM 287 & $1717 / 8$ & WS & Mardin & $\begin{array}{l}\text { Church of the Forty } \\
\text { Martyrs }\end{array}$ \\
\hline CFMM 289 & $17^{\text {th }} / 18^{\text {th }}$ & WS & Mardin & $\begin{array}{l}\text { Church of the Forty } \\
\text { Martyrs }\end{array}$ \\
\hline CFMM 293 & $19^{\text {th }}$ & WS & Mardin & $\begin{array}{l}\text { Church of the Forty } \\
\text { Martyrs }\end{array}$ \\
\hline CFMM 303 & $18^{\text {th }} / 19^{\text {th }}$ & WS & Mardin & $\begin{array}{l}\text { Church of the Forty } \\
\text { Martyrs }\end{array}$ \\
\hline CFMM 306 & $16^{\text {th }} / 17^{\text {th }}$ & WS & Mardin & $\begin{array}{l}\text { Church of the Forty } \\
\text { Martyrs }\end{array}$ \\
\hline CFMM 391 & 1722 & WS & Mardin & $\begin{array}{l}\text { Church of the Forty } \\
\text { Martyrs }\end{array}$ \\
\hline CFMM 556 & $16^{\text {th }} / 17^{\text {th }}$ & WS & Mardin & Church of the Forty \\
\hline
\end{tabular}




\begin{tabular}{|l|l|l|l|l|}
\hline & & & & Martyrs \\
\hline DIYR 241 & $1934^{2}$ & WS & Diyarbakir & Meryem Ana Church \\
\hline MGMT 137 & $1881 / 2$ & WS & Midyat & $\begin{array}{l}\text { Mor Gabriel } \\
\text { Monastery }\end{array}$ \\
\hline SMMJ 10 & $1474 / 5$ & WS & Jerusalem & St. Mark's Monastery \\
\hline SMMJ 43 & 1552 & WS & Jerusalem & St. Mark's Monastery \\
\hline SMMJ 44 & $1889^{3}$ & WS & Jerusalem & St. Mark's Monastery \\
\hline SMMJ 46 & 1852 & WS & Jerusalem & St. Mark's Monastery \\
\hline SMMJ 133 & $1678 / 9$ & ES & Jerusalem & St. Mark's Monastery \\
\hline SMMJ 140 & 1866 & WS & Jerusalem & St. Mark's Monastery \\
\hline SMMJ 167 & 1882 & WS & Jerusalem & St. Mark's Monastery \\
\hline SMMJ 168 & $17^{\text {th }}$ & WS & Jerusalem & St. Mark's Monastery \\
\hline SMMJ 201 & 1903 & WS & Jerusalem & St. Mark's Monastery \\
\hline SMMJ 238 & $18^{\text {th } / 19^{\text {th }}}$ & WS & Jerusalem & St. Mark's Monastery \\
\hline SMMJ 239 & $15^{\text {th }}(?)$ & WS & Jerusalem & St. Mark's Monastery \\
\hline SOAA 148 & $16^{\text {th }}$ & WS & Aleppo & $\begin{array}{l}\text { Syriac Orthodox } \\
\text { Archdiocese }\end{array}$ \\
\hline SOAH 3 & 1720 & WS & Homs & $\begin{array}{l}\text { Syriac Orthodox } \\
\text { Archdiocese }\end{array}$ \\
\hline
\end{tabular}

As the rest of the papers in this and the previous issue of Hugoye illustrate, the use of Syriac for writing another language is hardly confined to Arabic, but there are more manuscripts of Arabic Garshuni than other languages (Armenian, Kurdish, Turkish, etc.) in Syriac script. ${ }^{4}$ (To these languages the mention of Georgian may be added, thanks to a trisagion in Georgian [and other languages] written in East Syriac script in CCM 10, f. 8 r. $^{5}$ )

2 This is the date for the part of the manuscript that is cited below.

${ }^{3}$ The part of this manuscript referred to below was completed in 1889 , but what is now the second part of the manuscript was completed in 1506.

${ }^{4}$ George Anton Kiraz, Țürāss Mamllā: A Grammar of the Syriac Language, vol. 1: Orthography (Piscataway, NJ: Gorgias Press, 2012), 291-322.

${ }^{5}$ See a photograph and my brief discussion of it on the hmmlorientalia blog (Oct. 24, 2013) at http://wp.me/p21AWp-zw. Elsewhere, the Georgian trisagion is written in Armenian letters: in Matenadaran 4618 and 7117 (in the latter also the names of the letters of the Georgian alphabet). See Andrea Schmidt, "Arménien et syriaque," in C. Mutafian, ed., Arménie : la magie de Pécrit (exposition, Marseille, Centre de la vieille charité, 17 avril-22 juillet 2007) (Paris, 2007), 345-348, and J. den Heijer and A. Schmidt, "Scripts beyond borders: Allographic traditions and their social, cultural and philological aspects. An analytical introduction," in J. den 
Julius Assfalg ${ }^{6}$ characterizes Garshuni evidence as mostly coming from Maronite and West Syriac manuscripts, with less in East Syriac, but thanks especially to the accessibility of digital photographs of a large number of manuscripts in Iraq and elsewhere from predominantly East Syriac collections, 7 this picture can be challenged. ${ }^{8}$ Similarly, while at the time of his writing, the Mingana collection was the richest known in Garshuni, 9 the digital photographs of collected manuscripts now available through HMML from various churches, monasteries, and private libraries in Turkey, Lebanon, Syria, Jerusalem, and Iraq make this the single most copious stopping-place.

There are over eight hundred manuscripts in Arabic Garshuni that have been cataloged in HMML's recent work. These come from collections in Turkey (Mardin, Diyarbak1r), Jerusalem, Lebanon, Syria, and Iraq. I emphasize that these are several hundred manuscripts: the number of texts is, of course, far greater, not a few individual manuscripts containing upwards fifteen to twenty separate texts, or more (especially in the genres of hagiography and homilies). Many more Garshuni manuscripts remain to be cataloged.

Garshuni sometimes appears in unexpected places, as in SMMJ 281, a twentieth-century Gə 'วz manuscript that has a Garshuni note at the bottom of $\mathrm{f} .181 \mathrm{r}$. It says that the copy was presented (to Saint Mark's, presumably) from Empress Zawditu in 1916 by Gäbrä Śəlase "the minister (wažrir) of Ethiopia." It is notable that whoever penned this note used the etymological Arabic spelling

Heijer, A. Schmidt, and T. Pataridze, eds., Scripts Beyond Borders. A Survey of Allographic Traditions in the Euro-Mediterranean World, Publications de l'Institut Orientaliste de Louvain 62) (Louvain-la-Neuve, 2013), 1-63. I thank Hidemi Takahashi and Andrea Schmidt for referring me to these articles.

6 "Arabische Handschriften in syrischer Schrift (Karšūnī)," in Wolfdietrich Fischer, ed., Grundriß der arabischen Philologie, Bd. 1: Sprachwissenschaft (Wiesbaden: L. Reichert, 1982), 297-302, here 298.

7 This digitization work was carried out by the Centre numérique des manuscrits orientaux (CNMO) in partnership with the Hill Museum \& Manuscript Library (HMML).

${ }^{8}$ Just a few East Syriac Garšhūnī manuscripts, some of which are also mentioned below, are the following: CCM 3, 6 (16 th cent.?), 7, 8, 69 (1720), 74 (1647), 88 (1635), 338 91699/1700), 388, and 390; SMMJ 133.

${ }^{9}$ Assflag, 298, n. 14. 
with / $\theta /$ to spell the name Śəlase (بالبا. spelling.

In addition, there are some unexpected works to be found in Garshuni manuscripts. While biblical texts, homilies, works of Christian theology and liturgy, and kindred works occasion no surprise, to find The Story of Sindbad, medical books, and Catholic writings translated from Latin are another matter. Since some Catholic traditions use Arabic, the last mentioned kind of work is not a complete surprise, however, and we actually have some details about how such works came to appear in Garshuni. CFMM 114 and 115, for example, contain part of Cornelius a Lapide's (1567-1637) voluminous commentary on the Bible. (His surname, originally van den Steen and latinized as Lapide, becomes al-hağari in Arabic.) These copies are the work of the same scribe, 'Abd alMasih b. Buțrus, a Maronite of Aleppo; CFMM 115 is dated 1717. Sponsored by Michael Farhāàt (brother of Germanos Farhāàt), a Maronite scholar named Yūsuf b. Ğirğis al-Bānī translated them into Arabic in 1715, as stated in the rubrics. Significantly, these Mardin copies are quite early, earlier than any of the manuscripts that Graf (GCAL III 386-387) lists for the work. It might be unexpected to find a Maronite text in a Syriac Orthodox collection, but this one has been in place there for a rather long time, because, according to donation-notes in each book, they were donated to Dayr al-Za áfarān by Patriarch George III of Mosul (1745-1768). While the colophons of some Garshuni manuscripts have phrases like "translated into Garshuni" (see below), the rubrics for both of these texts have only "into Arabic." Given the very early date of these copies, however, it is certainly possible that Cornelius a Lapide's work first appeared in Arabic with Syriac letters, not Arabic letters.

We must also mention Syriac-Garshuni parallel texts. Not all, but many, of these are biblical texts, such as SMMJ 239; there are many others. These deserve further study from several viewpoints because in their arrangement they show us a specific fossilized relationship of Syriac and Arabic/Garshuni. What is the text type of the Arabic version(s)? How does it stand in relation to the Syriac parallel? Did the same scribe write both columns? If so, why is there nevertheless sometimes a difference in ductus, etc., as in the case of SMMJ 239, in which the Garshuni column was written with a pen of finer nib than the Syriac column, while in other cases, such 
as CCM 64, there is no such difference in the writing? In SMMJ 239, too, many of the Syriac titles are in Estrangelā, but the corresponding Garshuni titles are simply in Serțo, like the rest of the text in both languages.

The presence of Arabic in manuscripts that mostly consist of texts in Syriac often means that the Arabic there is also written in Syriac characters: at the margins of SOAA 148, f. $58 \mathrm{v}$, for example, a reader has penciled in the names of the planets in Garshuni beside the Syriac text of Bar 'Ebrāyā's short poem "On the Nature of the Seven Planets." But this is certainly not always the case. As an example, CCM 24 (Mardin 66), of the sixteenth century, has the

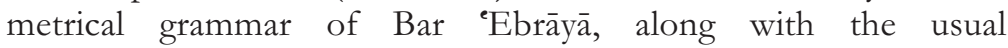
commentary, but there are also a number of contemporary notes and titles to the text in Arabic written in Arabic characters. This manuscript and others (e.g. CFMM 306 and SMMJ 133) also have quire identifiers-al-kurrās al-awwal, etc.-written in Arabic script; SMMJ 133 and CFMM 306 also have (at least some) catchwords in Arabic script, and at the end of the texts in the latter come short closing statements such as كمل بعون الله تعالى بالكمال (f. 38r). CCM 18, f. $78 \mathrm{v}$ shows a fine basmala in Arabic script, and elsewhere in the manuscript are other brief extraneous parts in Arabic script (e.g. kamulat on f. 216v). SMMJ 133 has several words, rubricated and not, in Arabic script: on f. 70r, at the end of one line, it has the last three letters of Sulayman in Arabic script rather than Syriac, Dāwüd is written completely in Arabic script at the end of a line on f. 72 r, and the same for al-nasr on $\mathrm{f}$. $73 \mathrm{r}$.

Cases of what we might call "reverse Garshuni"-Syriac language in Arabic script-are rare, but they do occur. ${ }^{10}$ Two notable examples are manuscripts of The Book of the Translator (Kitāb al-turğumān), Eliya of Nisibis's Syriac-Arabic lexicon arranged by topic: ${ }^{11}$ Syriac Orthodox Archdiocese of Homs (SOAH) 56 (1858 $\mathrm{AG}=1546 / 7 \mathrm{CE}$ ), ff. 4r-132v; and CCM 466 (18th c.?), f. 13v140r. ${ }^{12}$ Manuscripts of this work are most often found with two

\footnotetext{
${ }^{10}$ Kiraz, 323-325.

11 Adam McCollum, "Prolegomena to a New Edition of Eliya of Nisibis’ Kitäb al-turjumān fì ta 'lìm lugiat al-suryān," JSS 58 (2013): 297-322,

${ }^{12}$ I thank Grigory Kessel for pointing out the latter manuscript to
} esp. 310 . me. 
columns, Syriac and Garshuni, but these two copies have three columns: Syriac, Arabic, and Syriac in Arabic script. Another example, much less extensive, will be found in two words in CFMM 360, f. 283 r.

A few manuscripts have been adduced as possible examples of the oldest Garshuni. Assfalg points to BL Add. 14722, from the 13 th century, ${ }^{13}$ about which Wright notes, "The language is very incorrect and ungrammatical." 14 BL Add. 14493,15 which Wright dates to the tenth century, is mostly Syriac, but there are prayersalutations in Garshuni on f. 181r, introduced with the words, ILo; ("Prayers in Arabic [țayyāytā], written in Syriac [letters]."16

Garshuni is not confined to manuscripts. Thanks to Amir Harrak's edition of the inscriptions from Iraq, ${ }^{17}$ we have, for example, an easily accessible corpus of Garshuni inscriptions. One of these inscriptions (AD.01.01) with Garshuni is on a cross dated

13 Assflag, 298.

${ }^{14}$ Catalogue of Syriac Manuscripts in the British Museum Acquired since the Year 1838, vol. 2 (London, 1871), 1023.

${ }^{15}$ Cf. Martin R. Zammit's forthcoming article, "British Library Add. 14,493: A Very Early Garshuni Text," JSS.

${ }^{16}$ Catalogue of Syriac Manuscripts in the British Museum Acquired since the Year 1838, vol. 1 (London, 1870), 219-223. Further on early Garshuni, see Françoise Briquel-Chatonnet, Alain Desreumaux, and André Binggeli, "Un cas très ancien de garshouni? Quelques réflexions sur le manuscrit BL Add. 14644," in Pier Giorgio Borbone, Alessandro Mengozzi, and Mauro Tosco, eds., Loquentes linguis: Studi linguistici e orientali in onore di Fabrizio A. Pennacchietti = Linguistic and Oriental Studies in Honour of Fabrizio A. Pennacchietti $=$ Lingvistikaj kaj orientaj studoj bonore al Fabrizio $A$. Pennacchietti (Wiesbaden: Harrassowitz Verlag, 2006), 141-147; and Alessandro Mengozzi, "The History of Garshuni as a Writing System: Evidence from the Rabbula Codex," in Frederick Mario Fales and Giulia Francesca Grassi, eds., Camsemud 2007: Proceedings of the $13^{\text {th }}$ Italian Meeting of Afro-Asiatic Linguistics, Held in Udine, May 21 $1^{1 t}-24^{t h}$, 2007. History of the Ancient Near East, Monographs 10(Padova: S.A.R.G.O.N., 2010), $297-$ 304. Another relatively early Garshuni text is SMMJ 16, ff. 168r-177v (ms dated 1396/7); the scribe seems to be less skillful with Garshuni than with Syriac, assuming the same scribe wrote it as the one who wrote the Syriac parts of the manuscript.

17 Syriac and Garshuni Inscriptions of Iraq, 2 Vols., Recueil des inscriptions syriaques 2 (Paris: Académie des inscriptions et belles-lettres, 2010). 
1629/30 that has some Armenian on the same side, and Syriac and more Garshuni on the other, ${ }^{18}$ and the seventeenth century is indeed the time period of the earliest Garshuni inscriptions in Iraq. ${ }^{19}$ A very interesting feature of some of the Garshuni inscriptions that are translations from Syriac is that the translations rhyme, while the originals do not. ${ }^{20}$ As Harrak notes, the orthographic presentation of the Garshuni inscriptions is along the same lines as that seen in manuscripts, ${ }^{21}$ and in these we do find some stranger phenomena that occur, albeit rarely, in manuscripts, such as $\infty$ for $s$ and $\downarrow$ for $t$; the appearance of $x$ for $d$, which appears in inscription AD.01.15, I have not seen in manuscripts.

While Assfalg mentions the variability of scribal presentation of Arabic in Syriac letters, ${ }^{22}$ the simplicity of charts showing equivalents between typical writing of Arabic in Arabic letters and that in Garshuni in Syriac letters, such as that on p. 302 of his survey chapter, ${ }^{23}$ might deceive the unwary reader and belie for them this inconsistency. François Déroche describes as follows the time of the Arabic Hijāzī script, which was used in the second half of the seventh century and beginning of the eighth:24 "an age unaffected by official rules governing the script, unconcerned by a teaching of writing aiming at a perfect imitation of the model. Each scribe was writing in his way, following a general rule...." 25 Adam Gacek adds, "The scribes [of this period] may in fact have been more concerned about the transmission of the Qur'anic text than

${ }^{18}$ Harrak, vol. 1, 222-223.

${ }^{19}$ Harrak, vol. 1, 42.

${ }^{20}$ Harrak, vol. 1, 42.

${ }^{21}$ Harrak, vol. 1, 43-44.

22 "Es wird...weniger eine möglichst genaue Transliteration einer in arabischer Schrift vorliegenden (oder nur gedachten) Vorlage angestrebt, sondern mehr die Wiedergabe der Lautgestalt, jedoch ohne Konsequenz" (301). "A transliteration as exact as possible of something existing (or only thought) in Arabic script was aimed at less than merely the rendering of its form as it was pronounced, yet not consistently."

${ }^{23}$ See also Kiraz, 295-297.

${ }^{24}$ On this script, see Adam Gacek, Arabic Manuscripts: A Vademecum for Readers, Handbook of Oriental Studies 98 (Leiden and Boston: Brill, 2009), 123-125, where the following remark of Déroche is also cited.

25 Islamic Codicology: An Introduction to the Study of Manuscripts in Arabic Script, (London: Al-Furqan Islamic Heritage Foundation, 2006), 641. 
the appearance of their work." 26 These descriptions of Hijāzi manuscripts may also obtain for Garshuni manuscripts, not necessarily in terms of letter forms, but in terms of orthography, pointing, and vowels.

I will say a little more about dialect below, but at this point, I want to acknowledge that what is behind the written text is something that may fluctuate within certain parameters depending on the reader, whose own dialect and inherited reading tradition will, consciously or not, direct the act of reading. While we do well to keep this fact in mind, our focus here is the written text itself, without investigating in every case what possible dialectal realizations of that written text are possible.

The observations offered here derive mostly from my cataloging work, and thus, while I adduce manuscripts from both East Syriac and West Syriac provenance from various places, the picture presented here is not a comprehensive one based on all or even most known Garshuni manuscripts. Collections from Lebanon, for example, are not represented here, although there are hundreds of Garshuni manuscripts in those collections (and easily available through HMML). Nevertheless, I do not expect that the main point of this paper- that Garshuni ought not be thought of as more regular and consistent than the manuscripts show it to be-will be seriously challenged following a closer and more purposeful look at Garshuni manuscripts of a broader range of provenance than those included here.

\section{2. "INTO GARSHUNI"}

We meet commonly enough with simple references in Garshuni manuscripts to translation from Syriac into Arabic, as in the note on CFMM 414, p. 282, to pray for the translator of a certain polemical work, Zaytun of Anhel (d. 1855), ${ }^{27}$ who translated from Syriac (luğat al-suryānìa) into Arabic (lisān al-'arabìya), and we have this mention of Syriac-Arabic translation in CCM 13, f. 120r:

${ }^{26}$ Gacek, 124.

${ }^{27}$ Ignatius Afram Barsoum, The Scattered Pearls: A History of Syriac Literature and Sciences, trans. Matti Moosa (Piscataway: Gorgias Press, 2003), 522. 


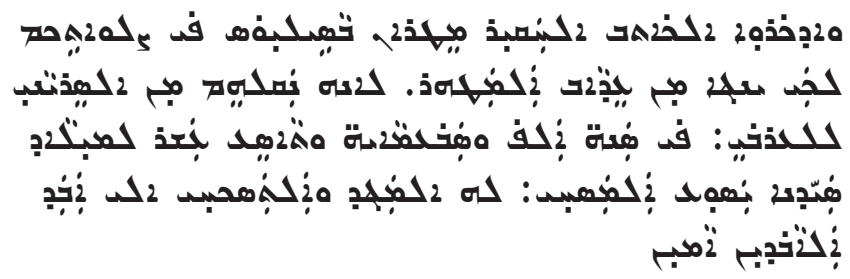

Remember in your prayers the poor scribe, Mutrān Basilios, that he might be delivered from the torment of purgatory, because he translated these [texts] from Syriac into Arabic in the year 1719 of the nativity of our Lord Jesus Christ, to whom be glory and praise forever and ever. Amen.

CFMM 104, ff. 464v-495r refers to translation from Syriac to Arabic, yet also with subsequent transliteration from Arabic into Garshuni. (This colophon belongs to the text itself, not the particular manuscript: it is also in CFMM 105, p. 678.) Similarly, in CFMM 95, p. 723, we find reference to the Gospel Commentary of Dionysius bar Salibi as translated from Syriac into Arabic by Rabbān 'Abd al-Nūr of Amid at Dayr al-Zaefarān, and then transliterated into Garshuni by a deacon named Dāwūd b. Yaeqūb:

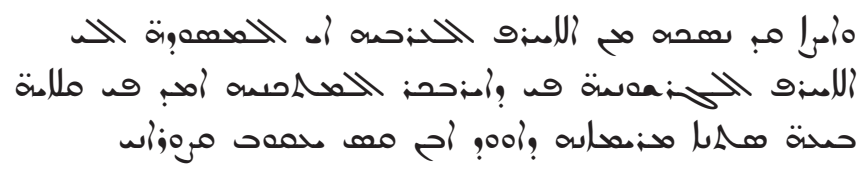

The deacon Dāwūd, son of Ya qūb Qașūrānī the priest, also transliterated it from Arabic letters- that is, in a rough draft [musawwada] —into Garshuni letters in Diyarbakır, which is named Āmid, in the cell of the Church of our Lady Meryem Ana.

Before presenting below some examples of Garshuni from several manuscripts, I would like to share a few places where scribes were conspicuously cognizant of Garshuni as a unique entity. As just seen, scribes sometimes make reference to their transcriptions from Arabic script into Syriac script. Scribes may also mention translation specifically from Garshuni into Syriac: in CFMM 256 (dated 1665), p. 344, at the end of The Story of Job the Righteous, the scribe records, "It was translated from Garshuni into Syriac..." 


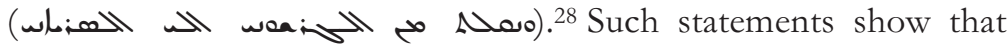
scribes certainly considered Arabic and Garshuni distinctly.

The colophon of SMMJ 167 (dated 1882) has a reference, not to the Garshuni "text" or "copy" (nusbua, as in SMMJ 140, f. 132v), but rather to "the Garshuni language" (lisän al-Garshuni). The scribe refers to a text unavailable at his own monastery, but a Greek priest from Beit Jala, "a friend of ours," had a copy to loan for his use. The scribe of SMMJ 167 says the following about this copy (ff. $322 \mathrm{r}-322 \mathrm{v})$ :

It was written in Arabic [mansūn 'arabiyyan], so we, the wretched, with his holiness, our revered lord, the honored Muțrān, Ǧirğis Mār Grigorios, were interested in transcribing it into the Garshuni language [bi-nasbibi fi lisän alGarshuni], so that reading it might be easy for the novice monks, that they might obtain the salvation of their souls.

This is not the only place where a Garshuni text is considered more readable to at least some section of the literate population. In this case, the audience in view is a group of beginning monks, and in the aforementioned manuscript SMMJ 140 the transcription from Arabic into Garshuni was made "to facilitate the understanding of its contents for every reader" (likeay yushal29 fahm madmünibi alá kull qäri, f. 132v). In the colophon of SMMJ 46, f. 365r, the scribe mentions that few Syriac Orthodox readers could read Arabic letters..$^{30} \mathrm{~A}$ text in SMMJ 44 was transliterated from Arabic into Garshuni, as the scribe says on f. 227v: "at the command [of Muțān Ğirğis of Șadad], it was transliterated [wa-șära naqlubu] from

${ }^{28}$ In the same manuscript, p. 349, after a Syriac story of Jonah, we have in Arabic script "... who transcribed and copied [naqala wa-kataba]

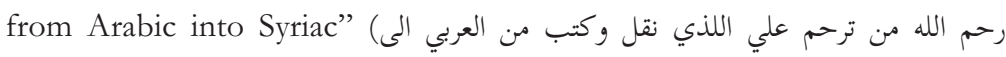

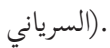

${ }^{29}$ Or yusabhala. The vowel a of the second syllable is so marked in the manuscript, but there is no $\check{s} a d d a$.

${ }^{30}$ As in SMMJ 44 and 144, the root n-q-1 refers, not to translation, but to transliteration from Arabic letters into Syriac letters. Similarly a seventeenth-century lectionary manuscript refers to the books'

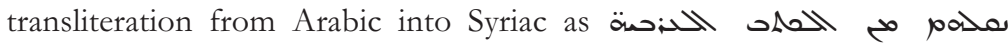
(CCM 45, f. 181r; the same in CCM 33, f. 155v, from the next century). 
Arabic into Garshuni script, so that it might be easy for readers" محامن:

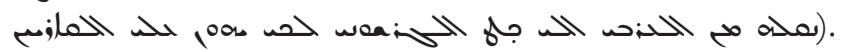

Finally, here are a few other references:

- MGMT 137, p. 50, has in the rubric a raid

- The label at the beginning of CFMM 104 has weaid

- The colophon of SOAH 3 specifically refers to its text's having been translated "into Garshuni."

- In SMMJ 10, f. 118v, a Garshuni-Syriac parallel Psalter, some of the Odes at the end of the book are only in Syriac, and the scribe apologizes for not having written those parts "in Garshuni" due to his not having a text for them to copy from.

\section{GRAPHOTACTICAL EVIDENCE}

Here, given the goal of this paper, I will do little more than list various instances of words or phrases from a number of Garshuni manuscripts. Each instance might well allow for lengthy comment and discussion, but for now it must suffice merely to emphasize the variety of Garshuni as realized in these manuscripts.

Before turning to some specific features of Garshuni, orthographic and otherwise, it bears mentioning, without going into details here, that at least some of these features reflect the spoken Arabic that the scribes and intended readers and hearers were used to, as in some other literary traditions. ${ }^{31}$ To mention only two relevant examples, I cite, for vowels, imāla ${ }^{32}$ and, for consonants, the shift of interdentals to dentals in the (later) Christian Arabic dialect of Baghdad: ${ }^{33}$

${ }^{31}$ For Middle Arabic, see Geoffrey Khan, "Middle Arabic," in Stefan Weninger, ed., The Semitic Languages: An International Handbook, in collaboration with Geoffrey Khan, Michael P. Streck, and Janet C.E. Watson (Handbücher zur Sprach- und Kommunikationswissenschaft 36. Berlin, De Gruyter, 2011), 817-835.

32 See, for example, Wolfdietrich Fischer and Otto Jastrow, eds., Handbuch der arabischen Dialekte, Porta Linguarum Orientalium, N.S. 16 (Wiesbaden: Harrassowitz, 1980), 55, and Haim Blanc, Communal Dialects of Baghdad (Cambridge, Mass.: Harvard, 1964), §3.36.

${ }^{33}$ Farida Abu-Haidar, Christian Arabic of Baghdad, Semitica Viva 7 (Wiesbaden: Harrassowitz, 1991), 7-9; cf. Fischer and Jastrow, 50; 
- tamara < tamara

- dahab $<$ dahab

- $\quad i d a<i d a$

- dagab $<$ zaraba (also with $\dot{g}<r$ )

One might discuss multiple such features from almost any Garshuni manuscript, and such analysis might also naturally contribute to the research of Arabic dialectology, especially since these graphic data are often tied exactly to a very specific time, place, and community.

\subsection{Vowels}

Vowels as written in Arabic are not uncommon, as in SMMJ 59. East Syriac Garshuni vowels at bottom few lines of CCM 54, f. $174 \mathrm{v}$, and in the same ms., f. $1 \mathrm{v}$, with rbassa arrikē for Arabic kasra in the word bisara. This vowel is also broadly used elsewhere: e.g. Arabic libna is يحتَ" and mabniy (SMMJ 133, f. 70r). The vowel rbāṣā karya is also loosely used, as the following clause bears

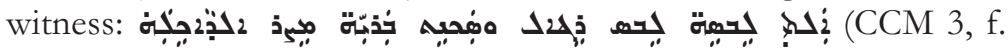
$27 \mathrm{v}$ ). (We may also note here the $\check{s} a d d a$ and two different ways of indicating the -at of the 3 fs perf.) The scribe of this manuscript was especially fond of this vowel, which occurs in some unexpected places, e.g. 2äså, (f. 27v) for the expected wa-

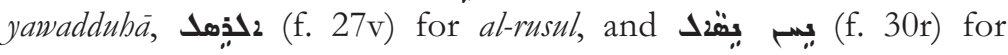
nahn(u) nas'al(u), and many more. These vowels thus written presumably reflect the scribe's Arabic dialect.

In CFMM 305, the final $-u$ is written in oul for ilthough rarely, the $u$ of perf. $1 \mathrm{cs}$ may be fully written with a pronominal

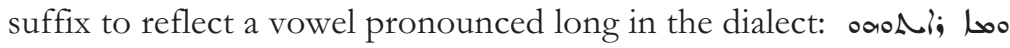
حسل oمعن/ (CFMM 304, p. 189).

As for the graphic realization of the Arabic a, CCM 11 on $44 \mathrm{v}$ and elsewhere has bustän written without an älap more than once, CCM 10, f. 41v, has $L_{j}$ for wasayya, and on f. $42 \mathrm{r}$ of the same manuscript nār appears as $\rightarrow$, on f. $43 \mathrm{r}$ bäb as حص, and on f. $51 \mathrm{r}$

Wolfdietrich Fischer, "Frühe Zeugnisse des Neuarabischen," in Fischer, ed., Grundriß, 83-95, here 85; Joshua Blau, "Das frühe Neuarabisch in mittelarabischen Texten,” in Fischer, ed., Grundriß, 96-109, here 101-102. 
ayyām as pr. (The common verb qäla, however, generally is written in this manuscript with älap.) (Conversely, another manuscript,

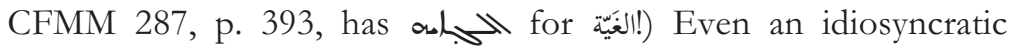
scribe like the one of CCM 11 could include a floating Syriac älap, like the Arabic "dagger alif," in the word dälik (f. 46r). The same scribe also very often includes Arabic vowel-signs, even though the accusative-marking alif is sometimes omitted, as in afle (f. 48r) for 'ağaban 'aziman, where both words are marked with the appropriate Arabic vowel-sign, but the second word has no accompanying alif (see further below on tanwin).

Alif maqșüra may be spelled with älap: CFMM 289, p. 45 and CCM 10, f. 42r, (and passim) have لـ fلى CCM 10, f. 41v, has تعالى CCM 63, f. 27v (Garshuni colophon to a Syriac lectionary), has مُبْتِ مُحَلّى for, and SMMJ 133, f. 67r, has

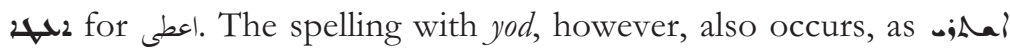
(DIYR 241, f. 88v), for example. Immediately after the aformentioned for in SMMJ 167, f. 67r, we find 2 , that is, in a single line of this manuscript we have two different ways of writing alif maqșüra. In CCM 10, f. 41v, and CCM 11, f. 43v, müsá is spelled with älap, not yod, which is more usual (e.g. CFMM 303, p. 2 and passim) and agrees with Arabic orthography. The spelling of the

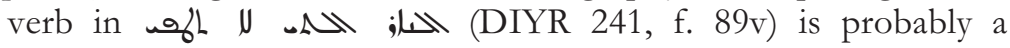
hypercorrection for tutfa', in either case with $-a^{\prime}>-\bar{a}$, written with an assumed alif maqșüra, just as in the first verb of الح:د (CCM 16, f. 21r; bada'a > badā). Strangely, بقي, which does not end in alif maqșüra, appears as حما in CCM 10, f. 46v.

The alif otiosum is usually written, but not always, as in (CCM 11, f. 44r) and oه (ibid., 44v).

A number of manuscripts regularly indicate the alif and the tanwin of the accusative, as in CCM 54 and SMMJ 238, e.g. خا

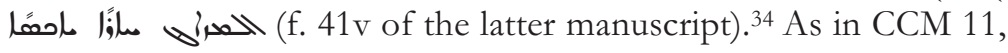
mentioned above, the alif to mark the accusative tanwin is not

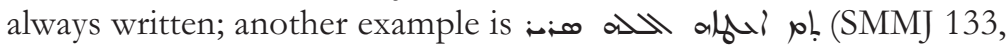
f. 67r), instead of 1 . The scribe of DIYR 241 (e.g. himäran and

34 The work here is a copy of 'Alī b. al-'Abbās' Complete Book of the Medical Art. 
awwalan on f. $289 \mathrm{v}$ ) marks the fatha with tanwin as two dots, not unlike the Syriac syamè in shape.

The -in is often marked with the Arabic vowel, as with سمبٍ in CCM 8, f. 84v (and elsewhere).

\subsection{Consonants}

Many manuscripts, such as SMMJ 239 (parallel Syriac-Garshuni) and CFMM 306, are carefully and consistently written so that the

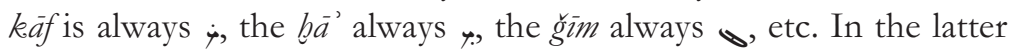

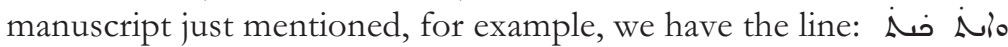

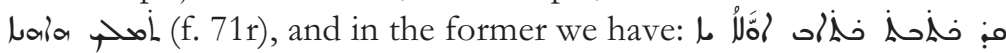
i i

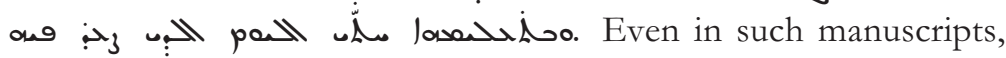
however, the dâl-däl distinction, although well marked in SMMJ 239 (and others, such as, in part, CFMM 391), may less consistently obtain, given these consonants' susceptibility to become confused in speech. In CCM 18, the word عمّ is even written this way on $\mathrm{f}$.

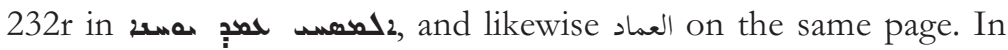
CCM 18 the $d \bar{a} l$ is marked with an underdot, but written in such a way that the Syriac dâlat simply has two horizontally parallel dots

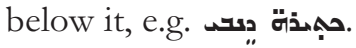

In SMMJ 133, ğ is represented by gamal with an angled tilde-like symbol, or even an extended form that looks like a small Arabic (dotless) ğim (as in CCM 11), beneath it, the common way for East Syriac Garshuni, ${ }^{35}$ while in Serto manuscripts it is generally represented by gamal and a dot within it. In both WS and ES Garshuni, gamal with a dot below often serves for gayn, as in متيه:نم (CCM 10, f. 51r). It is, however, not uncommon to find an unadorned gamal to indicate either the ğim or the gayn.

Now I list a few unusual phenomena related to the writing of consonants:

${ }^{35} \mathrm{It}$ is used also in Syriac manuscripts for the same sound, as in the colophon of CCM 62 (dated 1543), f. 201r, for the Islamic month-name Rağab. Syriac text editions by Bedjan sometimes have the gamal with this mark in certain place names, as in his edition of the Chronography of Bar

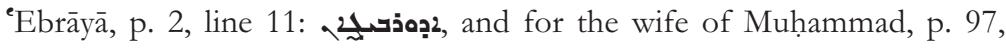
line 7: حيديح. 
1. A pee with dot above, just like the Arabic form, may stand for $\mathrm{f}$, but also a dotless pé. CFMM 304 has $f \vec{a}$ ' written with Syriac $p \bar{e}$ and underdot.

2. CFMM 287, p. 378 has "her brother" spelled lowi (not lowi).

3. At CFMM 290, p. 147, consonantal waws are spelled with two letters (as in some Hebrew and Jewish Aramaic orthographic traditions): aloa for قوّته This may, however, simply be a mistake, the scribe having wrongly written the letter twice.

4. SMMJ 33, 294r (a purchase- and waqf-note dated 1866) has $i d n$ spelled ,i, as does a similar note from the same year (same scribe?) in SMMJ 154, 206v.

5. CCM 10, f. 41v, مد 20 for and later in the same manuscript (f. 51r) we find 20 rasora, in which the first occurrence of the verb (I impf. $1 \mathrm{cs})$ is spelled with șädè, but the latter (IV impf. 1cs) again has it with semkat; on the spelling of oploz see above.

6. The scribe of CFMM 375 uses three dots under the taw for $\underline{t} \vec{a}$ ' (see e.g. p. 368, two lines from bottom).

7. CFMM 335, p. 10, has three dots under the bèt, like Persian , for / $/ p /$ in the word pir

Hardly unusual are copies that have less of the sought-after clarity and specificity. We may consider as an example just a few lines from CFMM 556 (an unidentified medical text that catalogs about

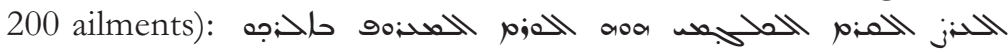

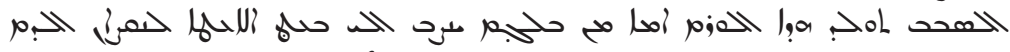
פم الحد: (the words al-aräd and al-sabab are rubricated). There are many letters that, in a more thoroughgoing and exact manuscript, would bear the expected diacritics.

Two consonants variably written across many Garshuni manuscripts are $z \vec{a}$ and $d \bar{a} d$. In Arabic script, too, they may be confused, as, for example, in this reader's note dated 1979 AG (=

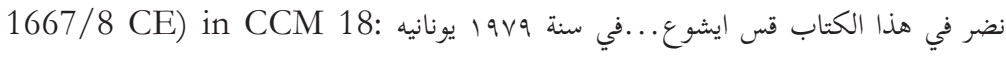
(with نظر instead of نظر نollowing for each of these two letters are some occurrences from several Garshuni manuscripts:

- for dād: 
- 20- 2CM 11, f. 43v and 45v, but with no dot on 44r)

- 20ل 20. (CCM 11, f. 44r)

- ט); (CFMM 391, p. 26)

- 42 (CCM 10, f. 49r; CCM 11, f. 43v; yet with no dot often, as in DIYR 241, f. 88v)

- الحم/ل (SMMJ 167, f. 106v; no dot, yet just below there is ofis $)^{36}$

- أل1 (CFMM 556, p. 337)

- בئf (CCM 11, f. 44r)

- ji (DIYR 241, f. 88v; CCM 10, ff. 48v, 50r)

- क; (CCM 16, ff. 37v, 40v)

- ف்َٔ (SMMJ 133, f. 70r)

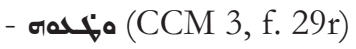

- محيه: (CCM 10, f. 51r)

- هله (CCM 10, f. 51r)

- مداهم (SMMJ 201, f. 135r)

- 20نة (SMMJ 133, f. 67r)

- معرe (DIYR 241, f. 88v, no dot)

- for $z a^{-3}$ :

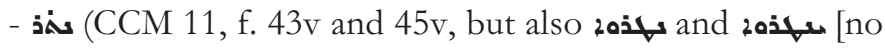
dot on 44r])

- ستخ (CCM 10, f. 49r)

- عهif (CCM 16, f. 38v)

- عه: (DIYR 241, f. 88v, no dot)

- 2حنغ (SMMJ 133, f. 67r)

- (CCM 10, f. 49r)

- שلهمA (CCM 16, f. 38v)

Needless to say, even when dots are present, they are not always correct. In SMMJ 43, f. 276v, for example, الحمناحم simply stands for المطابق.

${ }^{36}$ In the same manuscript, on f. $111 \mathrm{v}$, we find the expression both with and without (in a rubric) a dot. 


\subsection{Tašdīd, hamza, tā' marbūṭa, and related matters}

For the doubling of consonants (tašdidd) in Garshuni, the sadda, written just as in Arabic script, appears frequently, as in SMMJ 59, ff. $72 \mathrm{r}-73 \mathrm{r}$ (and in many other manuscripts, too). Elsewhere, a very obvious šadda (and a dot over the hè) in li-lläh (CCM 11, 43v), but elsewhere without the sadda (as on the next page of this manuscript). SMMJ 201 frequently marks the sadda. Just on f. $211 \mathrm{v}$, for example, we have, among others, al-aqliyya, al-abadiyya, ammā, alardiyya, and fa-innabu all marked with šadda. The šadda in SMMJ 201 appears more like a tilde than the typical Arabic shape, as in the phrase bi-quwwati sayyidina on f. 130r, in zamäniyya, and other words elsewhere, but the same sign appears over words that do not regularly have a $\check{s} a d d a$, such as abl on f. $131 \mathrm{r}$ and $\bar{u} l a \vec{i} i k a$ on ff. $128 \mathrm{v}$ and 135 r.

The hamza is very often simply omitted in the writing, as in $\mathbf{0} 25$ $230 \mathrm{~T} 2$ (CCM 8, f. 83v and passim), two words which should both technically have hamza. Other examples with medial hamza are

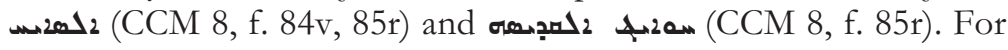

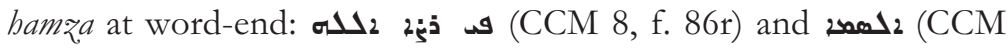
11, f. 44r). While it is more usual for the hamza to be omitted, it is sometimes written in Garshuni just as in Arabic script.

The tâ marbüta is indicated sometimes merely with $b$, sometimes with $h$ having two dots above, just as in Arabic, and in East Syriac Garshuni sometimes with $\mathrm{h}$ and only one dot above. The last mentioned way is evident even in manuscripts of Syriac works that cite Arabic words, as in a fifteenth-century (1458/9) copy of Yoahnnān bar Zoebi's grammar, where he mentions the Arabic words luga and lafza (CCM 20 f. 57v). (The corresponding words in the margin in Arabic script, which may have been written by the original scribe, have only a $h \vec{a}$ at the end, no dots.)

It is not uncommon to find feminine nouns with the $h \vec{a}$ having two dots, but adjectives having only $h \vec{a}$ (no dots), as in ت̈s (CCM 8, f. 83r). (The last word in this phrase has the zlama qašy $\bar{a}$ vowel as the vowel of the $t \vec{a}$ marbüta.) This goes for placenames, too: مجيدة 2 (CCM 8, f. 85v). On the other hand, we do also find adjectives with the $t \vec{a}$ marbüta clearly marked as such, as in حسم aive (DIYR 241, f. 88v). 
The word tawräh is written without älap in CCM 11, f. 43v, where it is in the construct state: 2000 öjos and it appears in CCM $10, \mathrm{f} .41 \mathrm{v}$, in the same spelling, but in CCM 16, f. 20v, it is written in accord with the usual Arabic way, äi;oN the title of The Colloquy of Moses is usually written a2s ow (e.g. CFMM 125, p. 260; CFMM 289, p. 248; CFMM 303, p. 2; CCM 16, f. 20v), but in CCM 10, f. 41v, it is written مبلم (i.e. without any älap), and in CFMM 293 (19th cent.), f. 111r ä2s w2, which matches Arabic orthography.

At CFMM 294, p. 23, the fem. pl. ending is spelled with $-b$ : عنامات occurs in the next line! The Arabic -at of the 3 fs perf. can be marked, instead of with the Syriac taw, with the same means as that for the $t \vec{a}$ marbüta, that is, the be having two

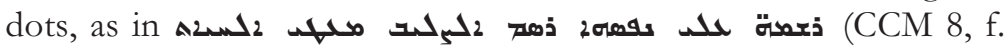

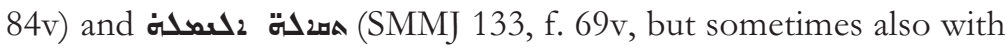
taw, as in (a) Three verbs with this phenomenon are in the

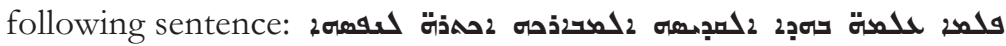

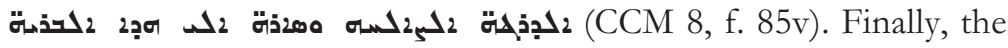
word bint is even written as though the $-t$ were a $t \vec{a}$ marbutta in CCM 11, f. 45v: حدتة

\section{CONCLUSION}

The Chinese quotation given at the beginning of this article reminds us that writing — of whatever kind — when tied to a reading tradition has the effect of bringing to hearers and readers "the names of many things." While there are among the world's languages some very close ties between script and language, those ties are not necessarily absolute and exclusive. In the case of Garshuni, those scribes who write it and the members of their intended audience know the speaking or reading tradition - that is, Arabic (the language, regardless of their knowledge of Arabic script) —and they know Syriac script, a writing system in any case not greatly differing in structure from that of Arabic script. Syriac script, even bare of the available diacritics that might otherwise help it mimic Arabic script more precisely, was apparently considered sufficient by these scribes and readers. Garshuni writing, to judge from its abundant attestation, served well for "writing the names of many things." 
The upshot of this look at some Garshuni phenomena from several manuscripts is that Garshuni is not quite so simple a matter as one might expect (and hope for) at first, and indeed as simple as one finds in some references to it in scholarly literature. Thankfully, with the easy availability of Garshuni manuscripts through HMML and other means, interested readers have vast opportunities to see Garshuni in action, not as described by this or that scholar (including the present one!), and not only in a published transliteration into Arabic script.

As I hope the mere presentation of the features above has shown, there is need for more research on Arabic Garshuni, as there is for other varieties of Garshuni. A systematic survey of the manuscripts, whether broadly, or of those from from specific regions or times, may reveal certain practices that were regular in some places and at some times that were not the norm in others, and thus give us a better idea of how the phenomenon has developed. 
